\title{
Biogas from slaughter house waste and optimization of the process
}

\author{
M. A. Rouf ${ }^{1 *}$, M. S. Islam ${ }^{1}$, T. Rabeya ${ }^{1}$, A. K. Mondal ${ }^{1}$, M. Khanam ${ }^{1}$, P. R Samadder ${ }^{2}$ and Y. Ara ${ }^{2}$ \\ ${ }^{1}$ Institute of Fuel Research and Development, Bangladesh Council of Scientific and Industrial, Research, \\ Dhanmondi, Dhaka-1205, Bangladesh. \\ ${ }^{2}$ Eden Mohila College, Dhaka-1205, Bangladesh.
}

\begin{abstract}
To assess the potential of biogas generation by anaerobic digestion from slaughter house waste (undigested stomach content) and to determine the optimum conditions for biogas generation from the substrate, different proportions of substrate were used in six batch reactors R1, R2, R3, R4, R5 and R6. The reactors were operated with initial volatile solid concentrations of 34.00, 50.80, 67.20, 51.60, 48.10 and 63.36 $\mathrm{g} / \mathrm{l}$ and corresponding specific gas production obtained was $0.258,0.200,0.160,0.270,0.201$ and $0.170 \mathrm{l} / \mathrm{g}$ respectively. The volatile solids (VS) destruction efficiency was $31.71 \%, 29.15 \%, 28.26 \%, 32.29 \%, 30.56$ and $29.08 \%$ as well as chemical oxygen demand (COD) reduction achieved in the test reactors were $40.31 \%, 44.44 \%, 49.40 \%, 53.24 \%, 48.55 \%$ and $51.26 \%$ in R1, R2, R3, R4, R5 and R6 respectively. Methane yield in different reactors varied from $72 \%$ to $76 \%$. The optimum mix for generation of biogas from the substrate was $75 \%$ slaughter waste mixed with $25 \%$ cow dung.
\end{abstract}

Keywords: Anaerobic digestion; Substrate; Volatile solids (VS); Chemical oxygen demand (COD); Methane yield

\section{Introduction}

As waste is an unavoidable byproduct of human activities as well as industrial activities, thousand tons of waste is generated from domestic, industrial, commercial, and institutional activities and these wastes have to be managed daily. Rapid increase of population growth ultimately causes rapid increase of urbanization and industrialization. But uncontrolled and unplanned urbanization has made waste management a serious problem today. The urban area generates approximately 16,015 tons of solid waste daily which add up to over 5.84 million tons annually (Waste concern, 2005).

The waste coming from the slaughter houses is polluting the surrounding environment, because in Bangladesh there is no organized system for disposal of both solid and liquid waste generated from slaughter houses. Poor management and treatment of slaughter wastes have been linked to pollution of surface water, underground water, air and the environment. The solid waste including hide, hair, undigested and digested food, bones and meat in general is collected and dumped or disposed off in open places which is an unhygienic practice. The waste is highly putrescible in nature and likely to have pathogens that could cause zoonoses. Liquid waste including blood, urine, washings of intestinal content in general is added to the municipal sewage system which is not desirable as it may contain objectionable components that may affect working of municipal sewage treatment plants. Pathogenic organisms are also found in slaughter house waste including Clostridium perfringens, Pseudomonas aeruginosa, Vibrio sp, (Adesemoye et al., 2006) Staphylo coccus sp, Salmonela sp, Proteus sp (Yakubu et al., 2007). The increased exposure of these organisms in the environment will cause diseases like food poisoning, cholera, urinary tract infections etc.

To save the environment and make the slaughter waste to resource, it is high time to think about the technological measure for resource recovery to combat environmental challenges. The term 'Resource Recovery' is used to describe the extraction of economically useable materials and energy from wastes (Ahmed and Rahman, 2003; Amin, 2009). Anaerobic digestion is considered as the best treatment method for recovering energy from waste in the form of biogas which is a renewable and echo-friendly blue burning gas. It contains mainly $50-70 \%$ methane $\left(\mathrm{CH}_{4}\right)$ and $30-50 \%$ carbon dioxide $\left(\mathrm{CO}_{2}\right)$ depending on the substrate as well as traces of hydrogen sulphide $\left(\mathrm{H}_{2} \mathrm{~S}\right)$, nitrogen $\left(\mathrm{N}_{2}\right)$, and hydro-

*Corresponding author. e-mail: roufmd@yahoo.com 
gen $\left(\mathrm{H}_{2}\right)$. This gas has a heating value of $21-24 \mathrm{MJ} / \mathrm{m}^{3}$ (Itodo et al., 2007; Bond \& Templeton, 2011).

Producing renewable energy from waste products through anaerobic digestion results in numerous advantages, including capturing and utilizing methane, a greenhouse gas 21 times more powerful than carbon dioxide, decreasing organic loading on receiving waters, and creation of a highnutrient, low-solid fertilizer (Huttunen et al., 2005; Kvasauskas 2009). Benefits of biogas include financial benefits (i.e; cooking and lighting fuel saving house hold's health related expenditure), social benefits (i.e; fertilizer saving, employment generation and poverty reduction), environmental benefits (i.e; green house gas emission reduction, reduction of deforestation, improvement of air quality etc). In Bangladesh, a lot of slaughter waste is produced all around the year especially during Eid-ul-Azha. At present, there is no organized system for disposal of such type of slaughter wastes. The solid wastes are either dumped or land filled and the liquid waste is washed away to the nearby river or canal. Although few research data are available regarding slaughter waste management, these are not satisfactory. Hence the objectives of the research work are: to assess the characteristics of the substrate of slaughter waste, examine the performance of biogas digester set up by using the substrate, optimize the parameters for biogas generation, and develop an appropriate technology for recovery of bio- energy from the substrate and study the economic feasibility of the technology.

\section{Materials and methods}

\section{Collection and preparation of sample}

The slaughter waste is a combination of all animal by-products including blood, hind gut, stomach content and fat scrubber content. We have taken only the stomach content for anaerobic digestion in a view to produce biogas. Slaughter waste was collected from different areas (Chalkbazar, Polashi Bazar, Hatirpul Bazar and Newmarket Bazar) at different times. The substrates collected were stored at $4^{\circ} \mathrm{C}$ before analysis and experiment. Some sample was pretreated in aerobic condition for 10 days by adding effluent from stable biogas digester in order to check the change of biogas production from pre-treated and untreated samples. The concentrations of the six biogas reactors on the basis of their contents are given below:

Reactor R1: 4\% solids (Slaughter waste 100\%+ 0\% cow dung)

Reactor R2: 6\% solids (slaughter waste 100\%+0\% cow dung)

Reactor R3: $8 \%$ solids (slaughter waste $100 \%+0 \%$ cow dung)

Reactor R4: $6 \%$ solids (cow dung 25\% + slaughter waste $75 \%$ )

Reactor R5: 6\% solids (100\% slaughter waste pretreated sample)

Reactor R6: 8\% solids (100\% slaughter waste pretreated sample)

The quantity of slaughter waste, cow dung and inoculums in different reactors are shown in Table I.

\section{Sample analysis}

Moisture and ash content were estimated by gravimetric method by drying at $105^{\circ} \mathrm{C}$ and by complete combustion at $800^{\circ} \mathrm{C}$. Calorific value was determined according to IS: 1350 (part 4)197 by bomb calorimeter. Total solid (TS) was estimated by subtracting the moisture content from $100 \%$ and volatile solid (VS) was estimated according to the procedure recommended in IS: $10158-1982$ by combustion

Table I. Quantity of slaughter waste, cow dung and inoculum in different reactors

\begin{tabular}{lccccc}
\hline Reactor & Slaughter waste $(\mathrm{g})$ & Cow dung $(\mathrm{g})$ & Inoculum $(\mathrm{ml})$ & Tap water & Volume of slurry $(\mathrm{ml})$ \\
\hline R1 & 200 & 0 & 100 & 700 & 1000 \\
R2 & 300 & 0 & 100 & 600 & 1000 \\
R3 & 400 & 0 & 100 & 500 & 1000 \\
R4 & 250 & 50 & 100 & 600 & 1000 \\
R5 & 300 & 0 & 100 & 600 & 1000 \\
R6 & 400 & 0 & 100 & 500 & 1000 \\
\hline
\end{tabular}


at $600^{\circ} \mathrm{C}$ for a couple of hours in the furnace. Carbon and nitrogen contents in the sample were determined with the help of C-N-H-S analyzer (Thermo Fischer Scientific, FLASH-2000) with TCD detector. Helium gas was used as carrier gas at $250 \mathrm{kPa}$ and $140 \mathrm{ml} / \mathrm{min}$, furnace and oven temperatures were maintained at $900{ }^{\circ} \mathrm{C}$ and $65{ }^{\circ} \mathrm{C}$ respectively. Chemical oxygen demand (COD) of the sample was estimated by oxidizing the sample with potassium dichromate then titrating with ferrous ammonium sulphate using ferroin indicator (APHA, 2000). Sample slurry $\mathrm{pH}$ was recorded using digital $\mathrm{pH}$ meter (HANNA, HI 98208) and gas composition was determined by gas chromatograph (Thermo Fischer Scientific, Trace GC Ultra with TCD detector). Helium gas was used as carrier gas at $900 \mathrm{kPa}$ and $10.5 \mathrm{ml} / \mathrm{min}$, detector and oven temperatures were maintained at $80{ }^{\circ} \mathrm{C}$ and $180{ }^{\circ} \mathrm{C}$ respectively.

\section{Characteristics of the substrate}

Characteristics of the substrate, cow dung and innoculm are shown in Table II. From the table, it is clear that characteristics of the substrate are almost similar to the characteristics of the universal substrate cow dung. The $\mathrm{C} / \mathrm{N}$ ratio of the substrate is 21 which is comparable to the standard value 20 to 30 (Rahman and Muyeed, 2010).

\section{Table II. Characteristics of substrates}

\begin{tabular}{lccc}
\hline Parameter & $\begin{array}{c}\text { Slaughter } \\
\text { dung }\end{array}$ & $\begin{array}{c}\text { Cow } \\
\text { waste }\end{array}$ & Inoculum \\
\hline $\mathrm{pH}$ & 7.60 & 6.21 & 6.43 \\
Moisture Content (\%) & 80.00 & 83.00 & 94.00 \\
TS (\%) & 20.00 & 17.00 & 6.00 \\
VS (\%) & 85.00 & 89.00 & 88.60 \\
COD (g/l) & 190.00 & 176.00 & - \\
C/N Ratio & 21 & 24.00 & - \\
Calorific Value (kcal/kg) & 3446.15 & 4658.07 & - \\
\hline
\end{tabular}

\section{Experimental Set up for anaerobic digestion in the laboratory}

The sample was fed into two liter capacity wide mouthed glass bottle on batch basis for 60 days at ambient temperature $\left(25^{\circ} \mathrm{C}\right)$. Volume of the substrate in the glass bottle was one liter. It was inoculated (10\% inoculum) with the sludge collected from an anaerobic plant based on cow dung. Six anaerobic reactors were set up with different concentrations of substrate. The total gas production was measured by water displacement method at an interval of 24 hours. Contents of the bottle were mixed manually after every gas measurement. Daily gas production was recorded.

\section{Results and discussion}

\section{Daily gas generation}

Figs. 1 to 6 represent the volumes of daily gas accumulation with varying amount of slaughter waste in different reactors. It was observed that gas generation started at the very next day of charging the digesters with the slurry. The rate of gas generation gradually increased with increasing the digestion period. All the fig. indicates that during the digestion period, most of the day gas production range was in between 200$400 \mathrm{ml}$. It was observed that peak gas production time was 20th, 23rd, 27th, 37th, 22th and 29th days of digestion period for R1, R2, R3, R4, R5 and R6 respectively. It was also found that the volume of maximum daily gas production was $600 \mathrm{ml}, 900 \mathrm{ml}, 1000 \mathrm{ml}, 1300 \mathrm{ml}, 800 \mathrm{ml}$ and $780 \mathrm{ml}$ for $\mathrm{R} 1, \mathrm{R} 2, \mathrm{R} 3, \mathrm{R} 4, \mathrm{R} 5$ and $\mathrm{R} 6$ respectively.

\section{Cumulative gas production}

The cumulative gas production from each of the test reactors operating at various organic loading of slaughter waste, and cow dung at the end of the eighth week of the study period is shown in Fig. 7. The figure shows that a cumulative production of $10350 \mathrm{ml}, 12000 \mathrm{ml}, 13100 \mathrm{ml}, 16330 \mathrm{ml}, 12200$ $\mathrm{ml}$ and $13500 \mathrm{ml}$ was observed in R1, R2, R3, R4, R5 and R6 biogas reactors respectively. The figure also shows that the lag phase prevailed up to 5 to 6 days of digestion period. This was due to microbe limiting at the initial stage of fermentation. The longer the lag phase the more delayed was the time of peak gas generation. After the lag period, the cumulative volume of gas increased sharply and continued up to 50 to 55 days of fermentation period followed by decreased gas generation and continued until the gas generation almost ceased. At the end of eighth week, gas generation in all the reactors almost ceased. 


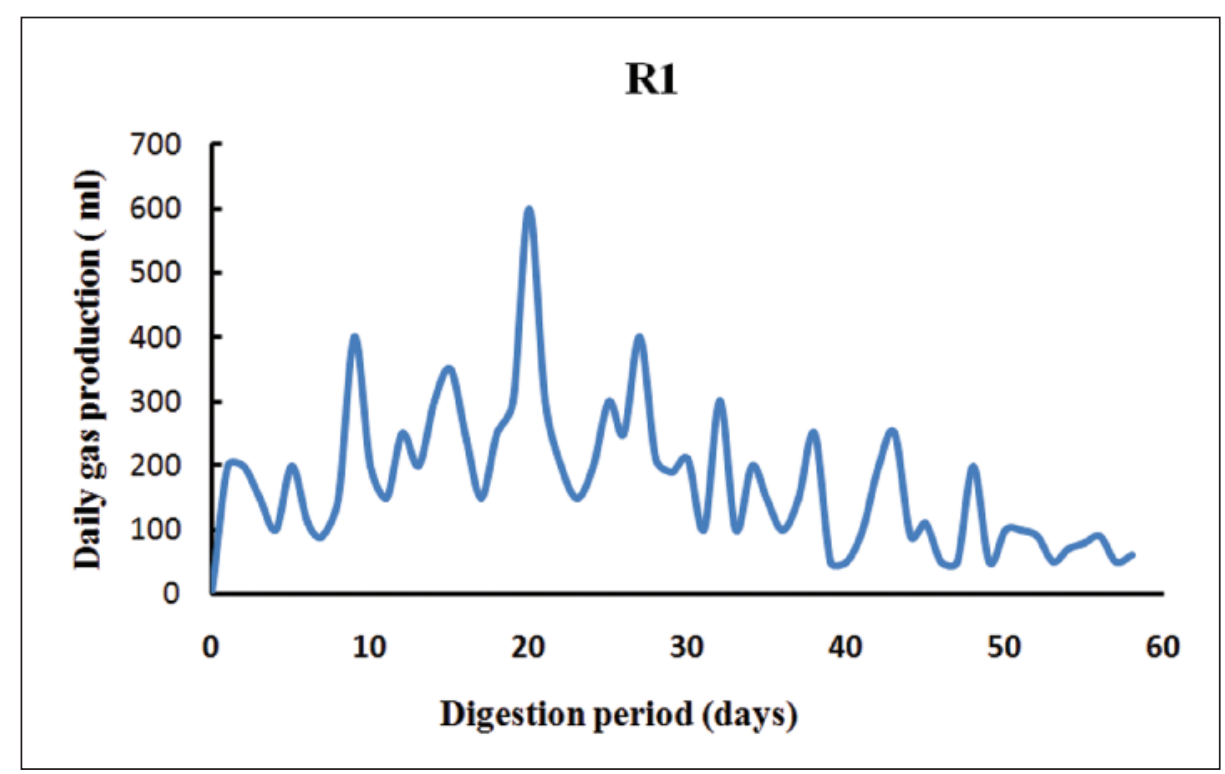

Fig. 1. Daily gas production during digestion period in R1 biogas reactor

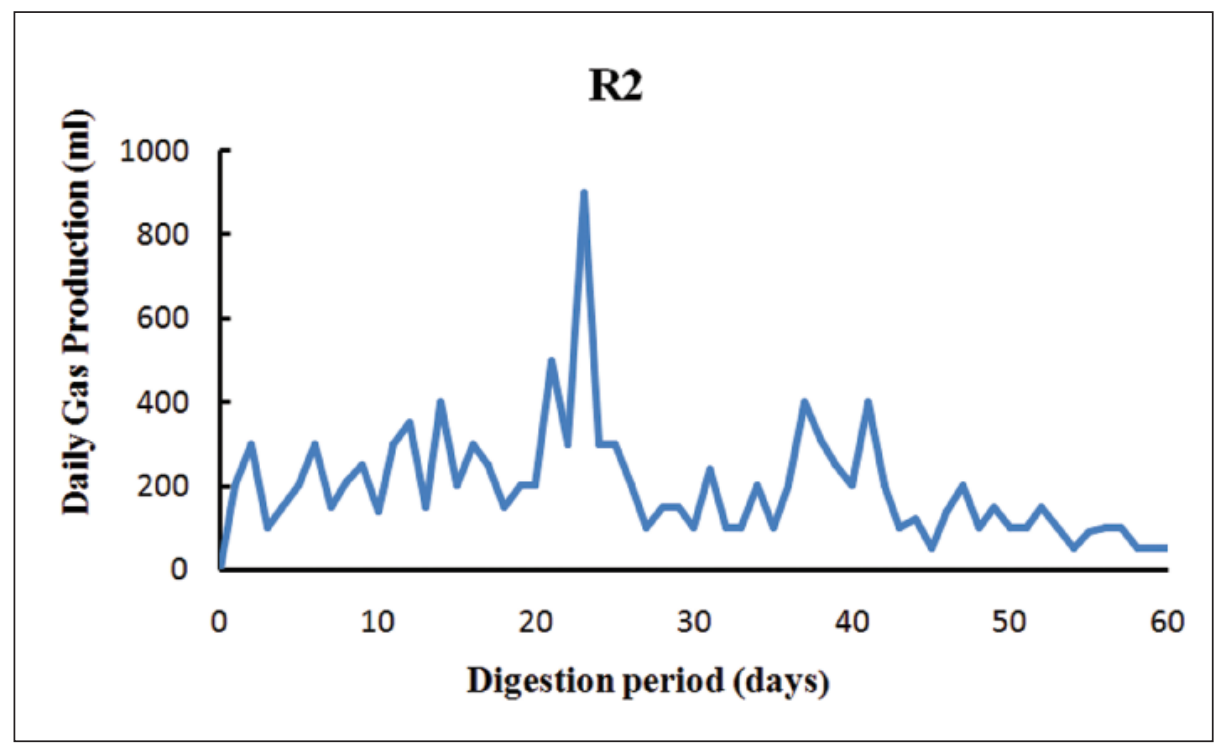

Fig. 2. Daily gas production during digestion period in $\mathrm{R} 2$ biogas reactor

\section{VS Destruction in Batch Reactor}

During anaerobic digestion of solid waste, biogas generation is specifically related to reduction of biodegradable fraction of VS in the digester and the degree of reduction depends on the initial volatile solids concentration of the slurry (Bosu, 1993). The trend curves of volatile solid destruction in different biogas reactors is shown in fig. 8 . The fig. shows percentages of volatile solids of slurry decreasing with increasing digestion period. VS reduction in the test reactors was observed in the range of $27 \%-33 \%$. These values are comparable with the VS reductions reported in the literature for various substrates (Rouf et al., 2010; Thangamani et al, 2009).

Variation of Gas Production after Every 10 Days

Variation of gas production after every ten days is shown in fig. 9. The fig. reveals that the variation of cumulative gas production after every ten days is very little except in R4 


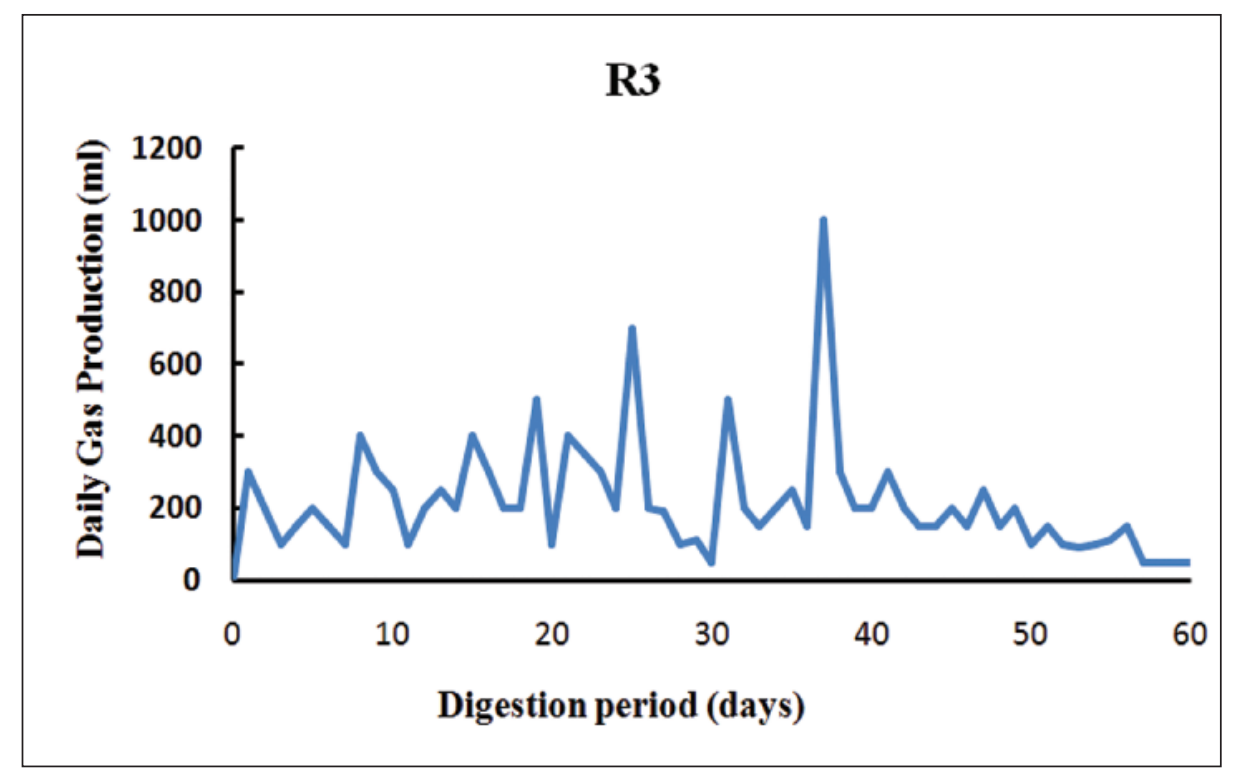

Fig. 3. Daily gas production during digestion period in $\mathrm{R} 3$ biogas reactor

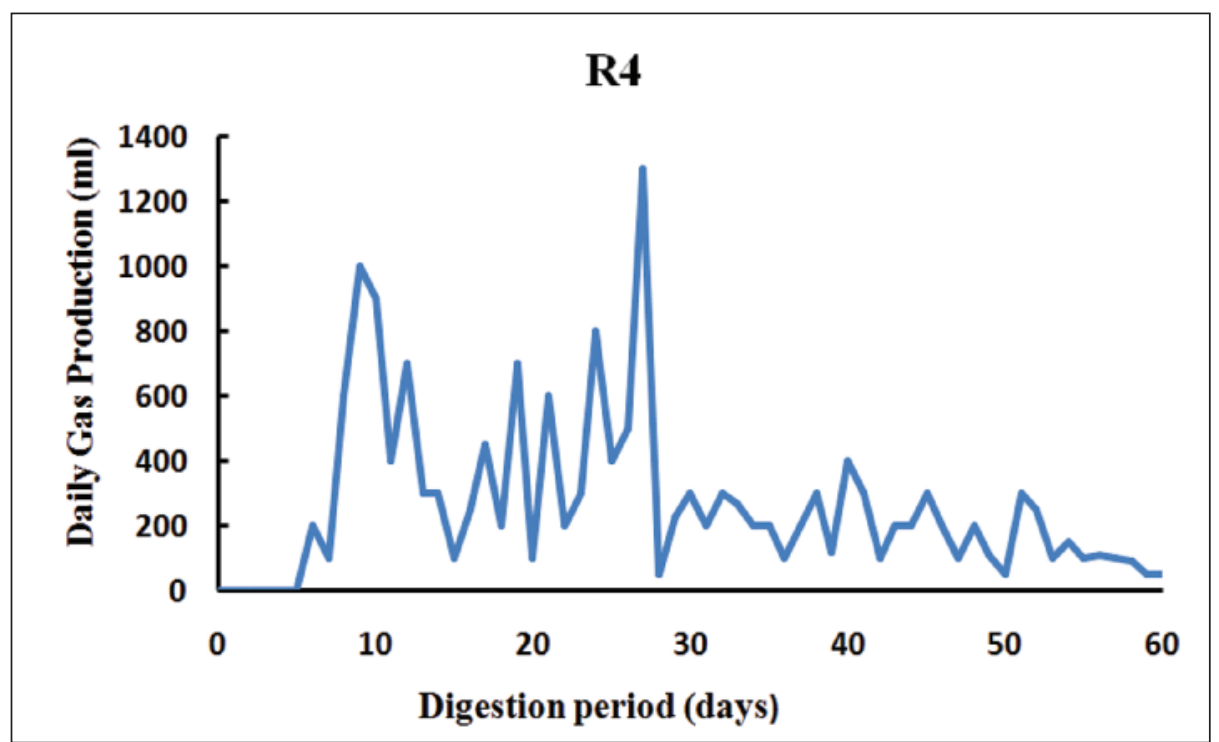

Fig. 4. Daily gas production during digestion period in $\mathrm{R} 4$ biogas reactor

(which consists of $75 \%$ SHW and $25 \%$ cow dung on $6 \%$ TS basis). The fig. also shows that maximum gas was produced in 3 rd cycle of ten days in this reactor.

\section{Effect of $p H$}

$\mathrm{pH}$ is another important parameter for biogas production. According to Rahman and Muyeed (2010), the desirable $\mathrm{pH}$ range is between 6.5- 8.0 and the highest gas yield was observed at Chengdu Research Institute was at $\mathrm{pH} 7.5$ to 8 .
$\mathrm{pH}$ profile of all the reactors are given in fig. 10. The fig. shows that $\mathrm{pH}$ values of all the six biogas reactors were in the range of 6.6 to 8.50 . This $\mathrm{pH}$ range is comparable similar to the study by Rahman and Muyeed (2010). The fig. also says that initial $\mathrm{pH}$ level of slurry of all the reactors declined, this is because in an anaerobic process, the acid forming bacteria are active at first and substrate is converted to acid quickly and as a result $\mathrm{pH}$ decreases. The methanogenesis then starts and increases the $\mathrm{pH}$ back to neutral or higher. 


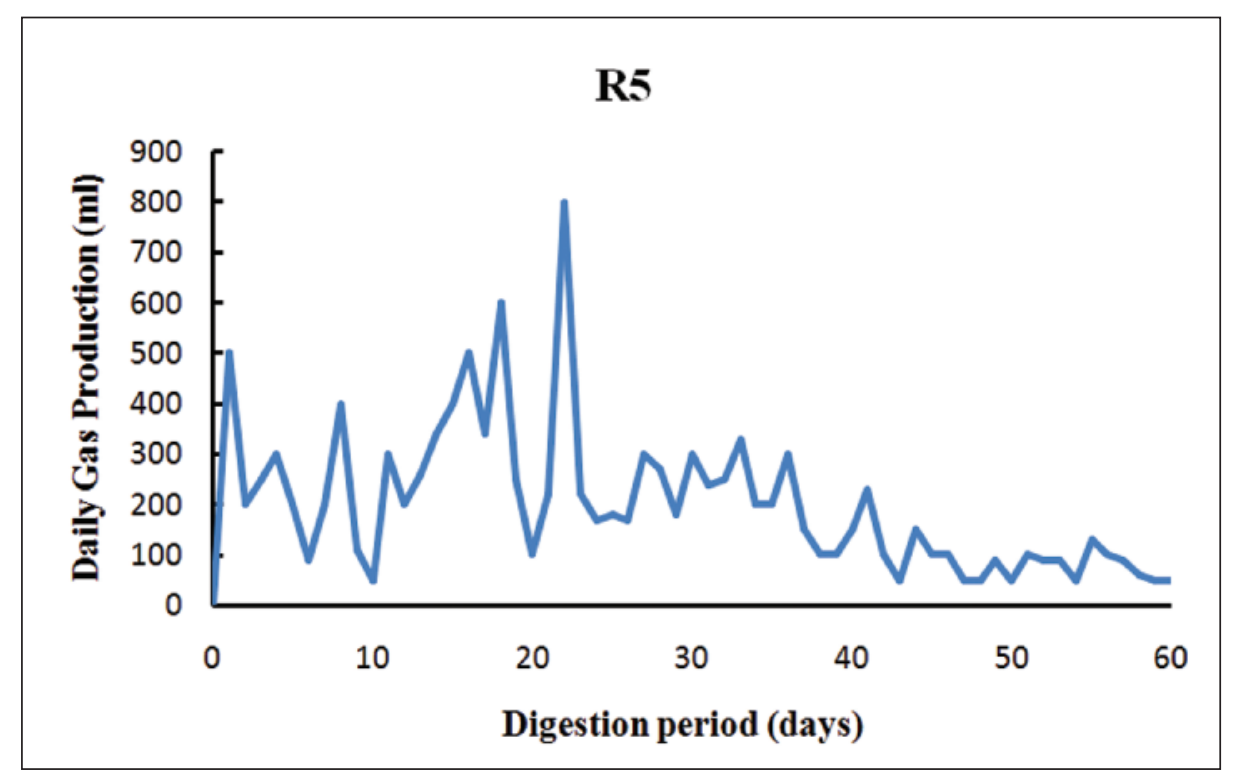

Fig. 5. Daily gas production during digestion period in $\mathrm{R} 5$ biogas reactor

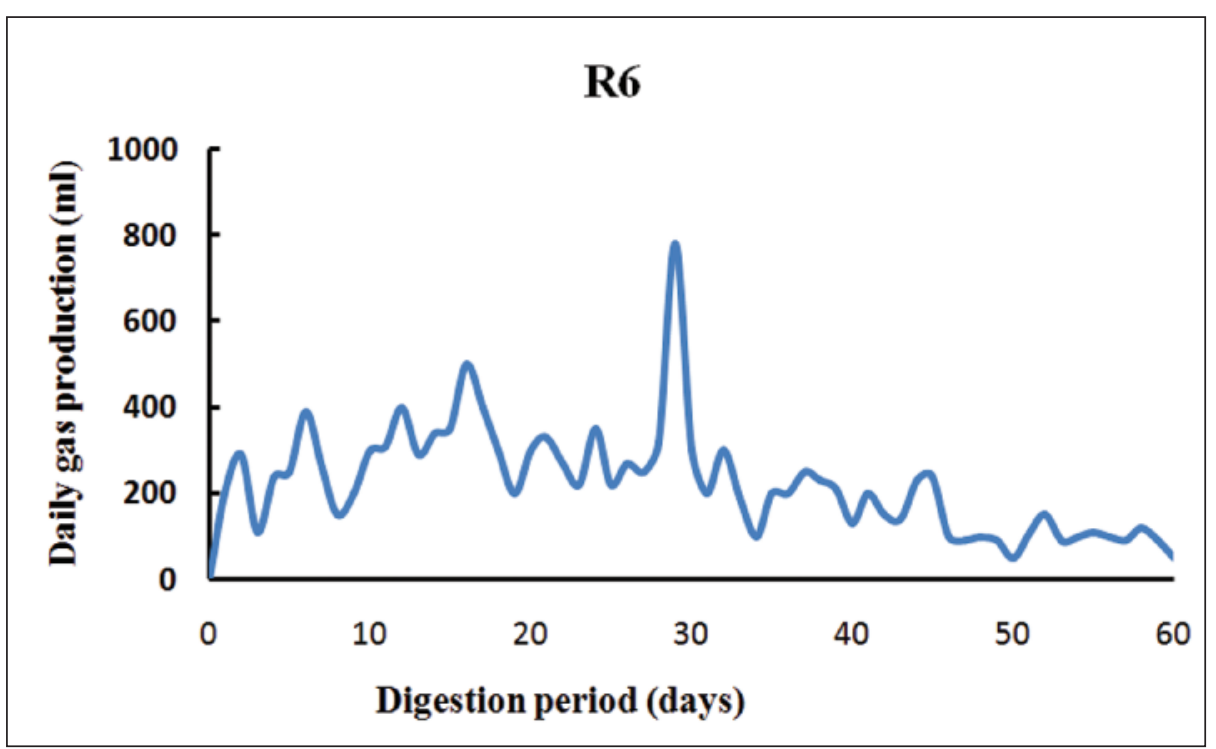

Fig. 6. Daily gas production during digestion period in $\mathrm{R} 6$ biogas reactor

\section{COD Reduction}

Chemical oxygen demand of the slurry is considerably reduced by anaerobic digestion treatment. The reduction of COD value means the reduction of pollution load from any substrate by the treatment process. The COD value trend curves for six different reactors are shown in fig. 11. The graph depicts that percentage of COD reduction for the six reactors are $40.31 \%, 44.44 \%, 49.40 \%, 53.24 \%, 48.55 \%$, and
$51.26 \%$ for R1, R2, R3, R4, R5 and R6 respectively. The trend line shows that good correlation exists between digestion time and COD value as the $\mathrm{R}^{2}$ value is above $95 \%$ for all the reactors. Maximum COD reduction was achieved from reactor $\mathrm{R} 4$ where maximum gas was produced. COD reduction is comparable to the reference value given by Rahman and Muyeed (2010). 


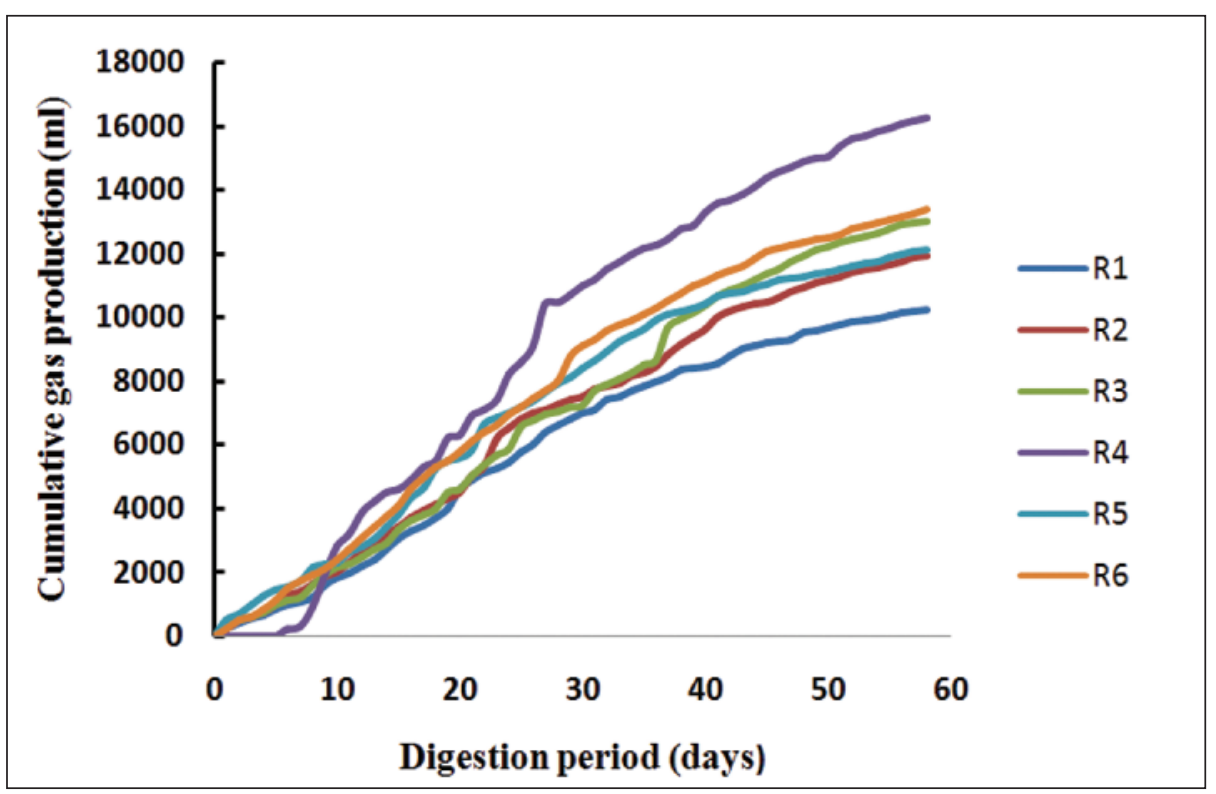

Fig. 7. Cumulative gas production in six biogas reactors

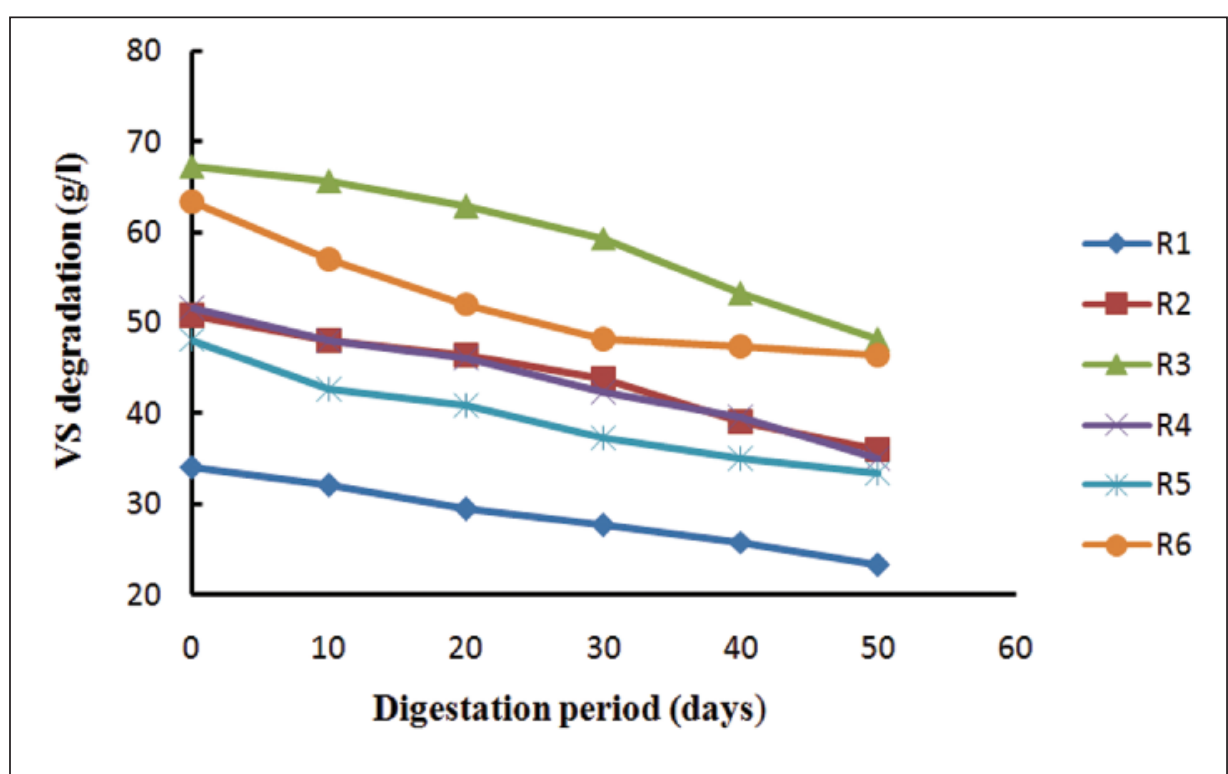

Fig. 8. VS degradation graph of six biogas reactors

Change of cumulative gas production with VS degradation

Fig. 12 shows that cumulative gas production in each reactor increases as VS destruction increases with time. This reveals that biogas production depends on concentration of biodegradable fraction of volatile solids.
Field level study

A $6 \mathrm{~m}^{3}$ fiber glass biogas plant $\left(3 \mathrm{~m}^{3}\right.$ gas production capacity per day) has successfully been installed at Tongi, Gazipur slaughter house (city corporation slaughter house) yard to produce biogas from slaughter house waste for field level study. A family of six is using it satisfactorily to cook all 


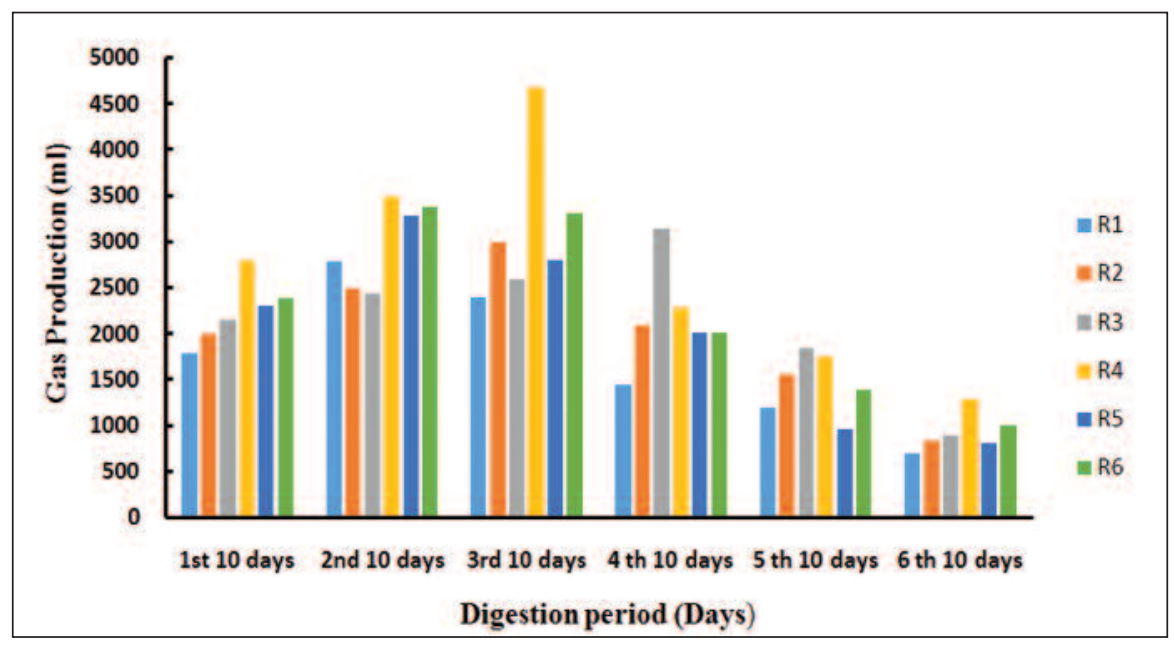

Fig. 9. Variation of gas production in six biogas reactors after every 10 days

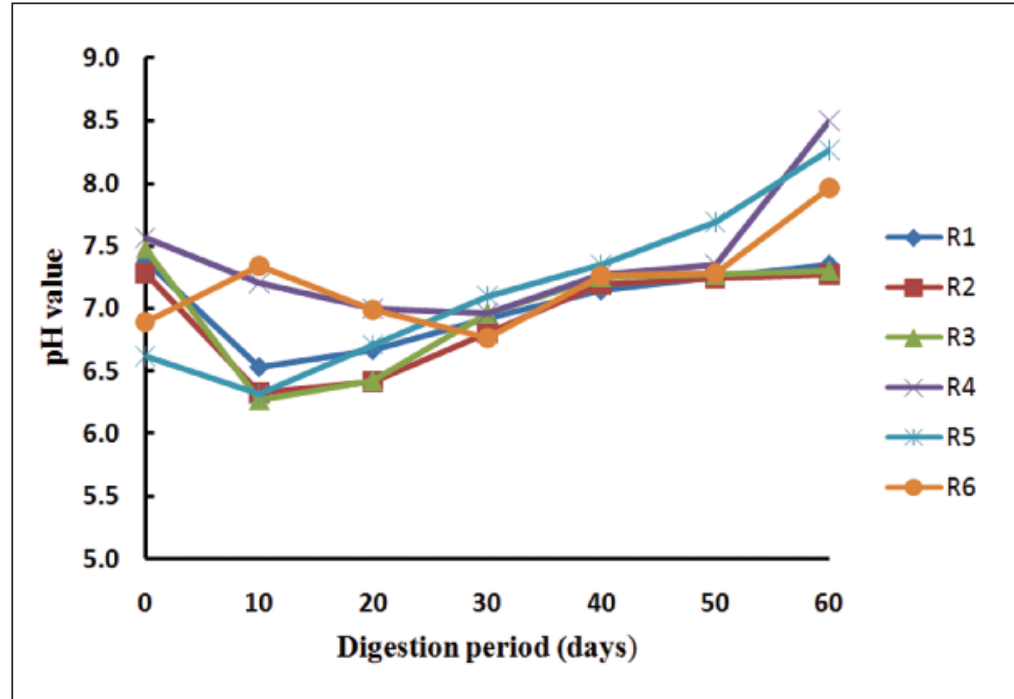

Fig. 10. pH profile for all the biogas reactors

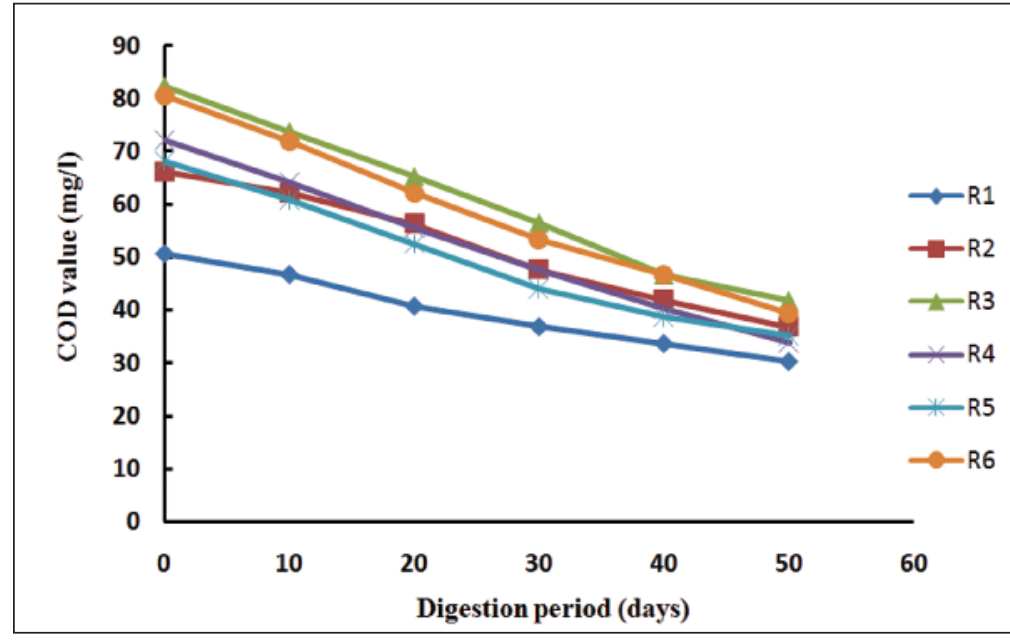

Fig. 11. COD value with time in six biogas reactors 


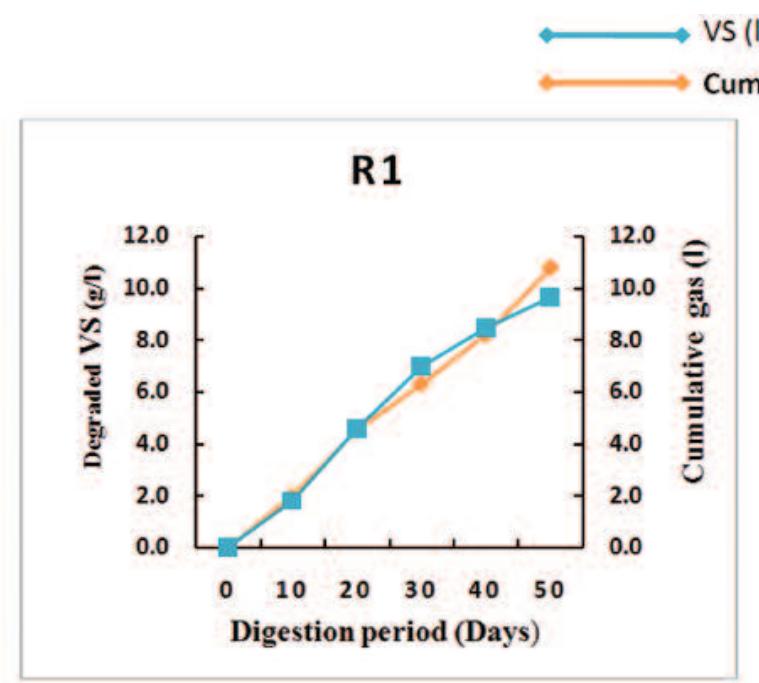

R2
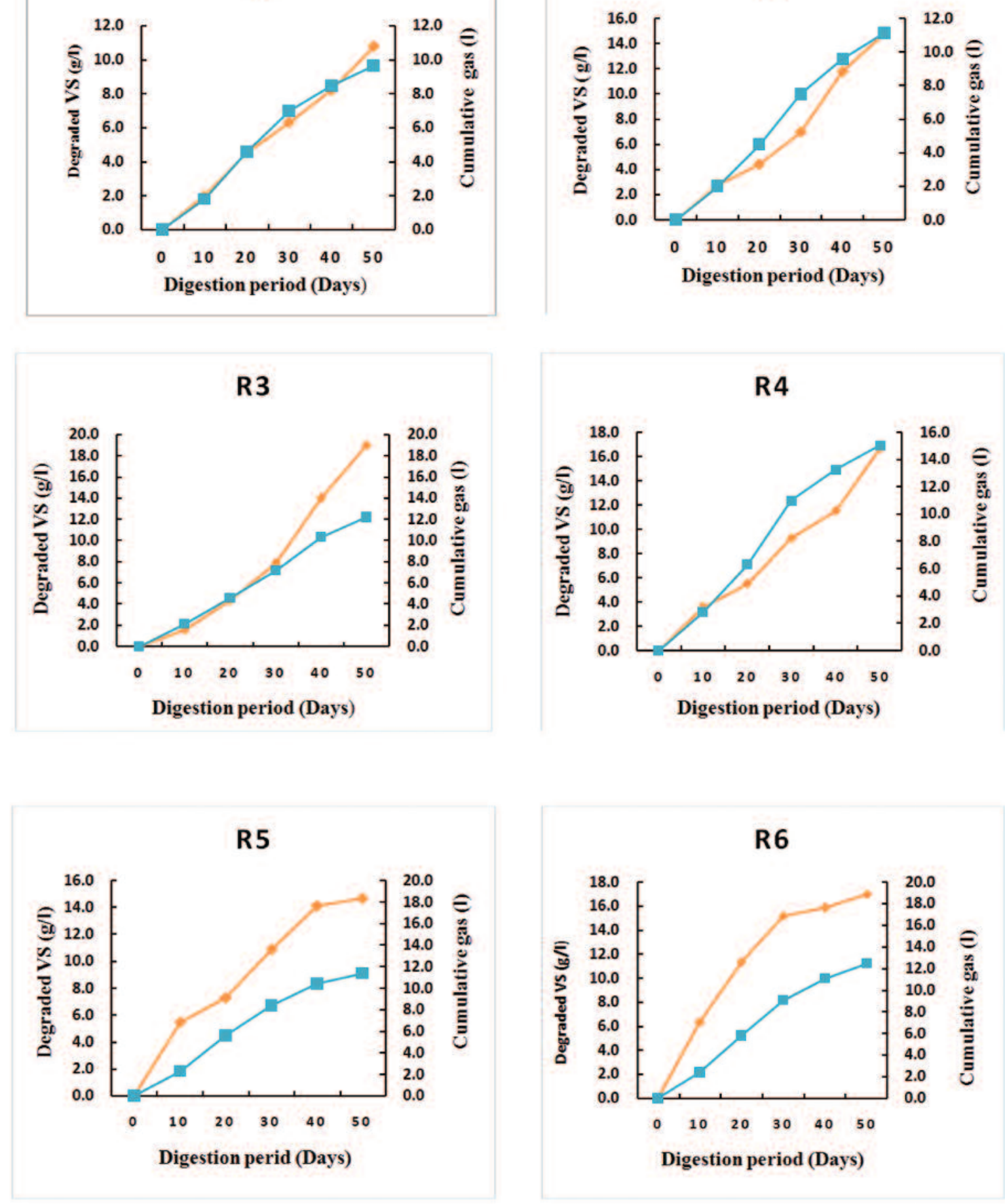

Fig. 12. Variation of cumulative gas production and volatile solid concentration with time in six biogas reactors 

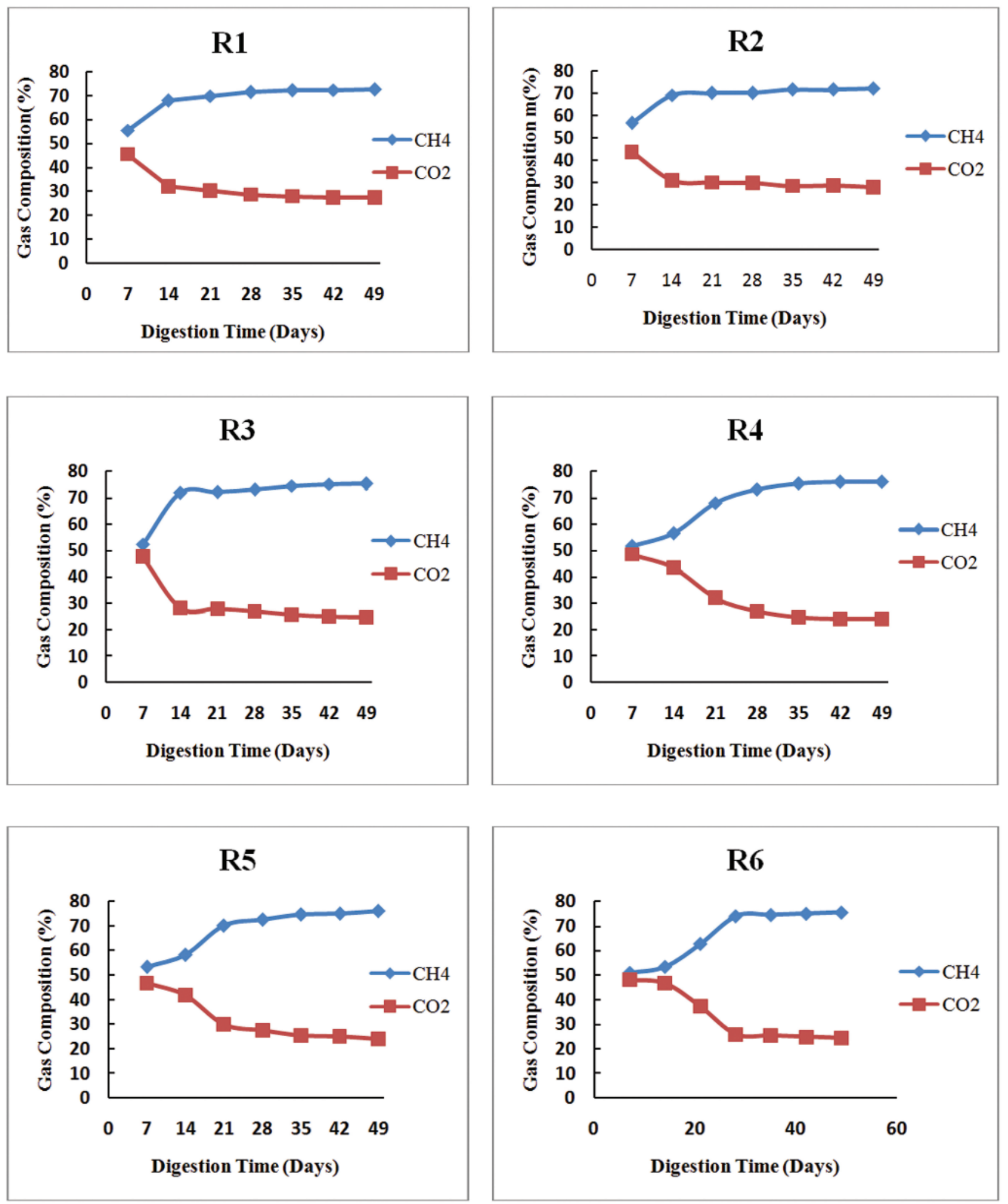

Fig. 13. Variation of gas composition with time in six biogas reactors 
their meals every day. $11 \mathrm{~kg}$ TS of slaughter waste is being fed per day to the plant.

\section{Gas composition}

Gas composition was measured several times to verify the quality of produced gas. Fig. 13 shows the variation of gas composition in different biogas reactors. In the first sevendays of digestion period, all the analysis showed lower $\%$ of methane. After 20 days of digestion period, $\mathrm{CH}_{4}$ percentage shows a higher percentage and it continues until gas generation stopped. Almost similar trend of gas composition is observed for all the reactors. Composition of methane is $72.50 \%, 72 \%, 75.30 \%, 76 \%, 75.50 \%$ and $75 \%$ in $\mathrm{R} 1, \mathrm{R} 2$, R3, R4, R5 and R6 respectively.

Table III shows comparative study of six biogas reactors. From the table, it is clear that optimum condition for biogas generation from the substrate is $75 \%$ slaughter waste mixed with $25 \%$ cow dung on $6 \%$ total solid basis.

Table III. Comparative study of six biogas reactors

\begin{tabular}{lccc}
\hline Reactor & $\begin{array}{c}\text { VS reduction } \\
(\%)\end{array}$ & $\begin{array}{c}\text { COD reduction } \\
(\%)\end{array}$ & $\begin{array}{c}\text { Specific gas } \\
\text { yield }(1 / \mathrm{g})\end{array}$ \\
\hline R1 & 31.71 & 31 & 0.25 \\
R2 & 29.15 & 44.44 & 0.236 \\
R3 & 28.26 & 49.49 & 0.194 \\
R4 & 32.29 & 53.24 & 0.316 \\
R5 & 30.56 & 48.55 & 0.252 \\
R6 & 29.09 & 51.26 & 0.213 \\
\hline
\end{tabular}

\section{Conclusions}

The performance of anaerobic co-digestion of slaughter waste is evaluated in terms of VS destruction, biogas yield and methane content. It is found that slaughter waste has high potential as substrates for biogas generation by anaerobic digestion. Based on the volatile solid destruction efficiencies and specific gas production, it is confirmed that slaughter waste is amenable for anaerobic digestion by mixing with cow dung. The optimum conditions for biogas generation from slaughter waste $(\mathrm{C} / \mathrm{N}$ ratio 21$)$ is $25 \%$ cow dung and $75 \%$ slaughter waste on $6 \%$ total solid basis. The methane content in the biogas is $72-76 \%$ and specific gas yield is $0.316(1 / \mathrm{g})$. Since energy is required in our everyday life as well as for the industry to run, hence recovery of energy from the slaughter waste by anaerobic digestion can be an appropriate, sustainable and environment friendly option for slaughter waste management.

\section{References}

APHA, AWWA and WEF (1992), Standard methods for the examination of water and wastewater (18 th Ed.), American Public Health Assn, Washington DC.

Adesemoye AO, Oper B and Makiwe S (2006), Microbial content of abattoir waste water and its contaminated soil in Lagos, Nigeria. African Journal of Biotechnology, 5(20): 1963-1968.

Ahmed MF and Rahman MM (2003), Water supply and sanitation rural and low-income urban communities. ITN Bangladesh, BUET Dhaka, Bangladesh. p 259.

Amin MN (2009), Resource recovery and zero waste management option of slaughter house waste in Khulna City Corporation of Bangladesh: J. Bangladesh Agril. Univ. 7(2): 321-327.

Bond T and Templeton MR (2011), History and future of domestic biogas plants in the developing world. Energy for Sustainable Development, 15: 347-354.

Bosu SK (1993), Effect of mechanical mixing and dung concentration on biogas generation, Msc. Eng. Thesis, Department of Civil Eng. Dhaka, Bangladesh .

Enayetllah I, Sinha AHMM and Khan SSA (2005), Urban solid waste management scenario of Bangladesh: problems and prospects Waste Concern Technical Documentation.

Huttunen S and Lampinen A (Eds.) (2005), Bioenergy Technology Evaluation and Potential in Costarica. University of Jyva skyla Printing House, Jyvaskyla, Finland.

Itodo IN, Agyo GE and Yusuf P (2007), Performance evaluation of a biogas stove for cooking in Nigeria. Journal of Energy in Southern Africa, 18(3): 14-18. 
Kvasauskas M (2009), Mažu gabaritu bioreaktoriaus tyrimai irkurimas [Research and design of small scale bioreactor]. Vilnius: Technika ISBN 978-9955-28-426-0.

Nwanta JA, Onunkwo JI, Ezenduka VE, Phil-Eze P, and Egege S (2008), Abattoir operations and waste management in Nigeria: A review of challenges and prospects. Sokoto Journal of Veterinary Sciences, 7(2):61-67.

Rouf MA, Bajpai PK and Jotshi CK (1999), Characterization of press mud from sugar industry and its potential for biogas generation, Proc. CHEMCON-99 (Indian Chemical Engineering Congress), Chandigarh, December 20-23, pa. RMA-158.

Rouf MA, Bajpai, PK and Jotshi CK (2010), Optimization of biogas generation from press mud in batch reactor, Bangladesh J. Sci. Ind. Res. 45(4): 371-376.
Rahman MH and Muyeed A (2010), Solid and Hazardous waste management, Published by ITN-BUET, Dhaka, Bangladesh, $1^{\text {st }}$ Ed. 179 - 214.

Thangamani A, Rajakumar S and Ramanujam RA (2009), Anaerobic co-digestion of hazardous tannery solid waste and primary sludge: biodegradation kinetics and metabolite analysis, Clean Techn. Environ Policy, Springer.

Yakubu AA, Garba H and Habibullah S (2007), A microbial and chemical assessment of abattoir effluent used for vegetable irrigation in Sokoto, Nigeria. Sahel Journal of Veterinary Sciences, 7: 1-4.

Received:15 December 2015; Revised: 03 March 2016; Accepted: 24 April 2016. 